\title{
Synthetic granite composite for precision equipment structures
}

\author{
João Fiore Parreira Lovo ${ }^{1}$, Marcos Paulo Gonçalves Pedroso ${ }^{1}$, \\ Rogério Erbereli ${ }^{1}$, Benedito de Moraes Purquerio ${ }^{1}$, \\ Carlos Alberto Fortulan ${ }^{1}$
}

\author{
${ }^{1}$ Tribology and Composites Laboratory - Department of Mechanical Engineering - EESC/USP, Trabalhador Saocarlense \\ 400, São Carlos, São Paulo, Brazil. \\ e-mail: joao.lovo@usp.br
}

\begin{abstract}
The structure is a component that plays an extremely important role in the equipment's performance, it must withstand efforts without compromising the function, receive and transfer heat, dampen vibrations and position the elements, as well as promote ergonomics and aesthetics. In lightweight and precision equipment's the raw material used must also allow thin walls, rigid, resistant and low density. The objective of the present work is the development of a synthetic granite composite for manufacturing of equipment's structures. For this, an abundant Brazilian granite, a high strength epoxy resin and segmented carbon fibers were selected as materials. Test specimens, with maximized packing with granite gravel less than $2.0 \mathrm{~mm}$ were fabricated and tested for tensile strength, compression, flexural, damping, hardness, dilatometry, thermal conductivity and density. The maximized composition supported flexural stresses above $42 \mathrm{MPa}$, without fiber reinforcement and $51 \mathrm{MPa}$ with carbon fiber reinforcement. The damping coefficient was about 7 times higher than cast iron, coefficient of thermal expansion of $1.4 \mathrm{E}-05 \mathrm{~m} / \mathrm{m} . \mathrm{K}$, thermal conductivity coefficient of $1.2 \mathrm{~W} / \mathrm{m} . \mathrm{K}$ and density of $2.1 \mathrm{~g} / \mathrm{cm}^{3}$. The developed composite showed potential for refining structures, with ease of molding of thin-walled elements, use of inserts, re-machining, providing economical manufacture of single parts, and is still able to perform the function with high damping coefficient and low weight.
\end{abstract}

Keywords: Synthetic granite, composite, machine structure, damping

\section{INTRODUCTION}

Structural materials play a key role in equipment's operation and performance. Thus, the material selection must ensure the performance of the device function in order to withstand stresses by providing adequate integrity and stability in service [1-3], meet specific needs such as strength, hardness, durability, rigidity, weight, heat and corrosion resistance, electrical conductivity, machinability, besides environmental characteristics and compatible cost with equipment value, the main structural materials generally used are cast iron, aluminum, composites in general and engineering polymers [1,4-6].

In modern engineering concept the equipment must have compatible dimensions with the products and environments with which they work [4,7], optimizing space and weight in the allocated environment. In a precision device the structure material must also enable the fabrication of elements with reduced dimensions, low deformation by thermal variations, and particularly vibrations dampening [8-11]. Manufacturing is another aspect that deserves to be highlighted, especially in small scale concept devices, since the investment in molds, casting and machining can become infeasible designs [7,12,13]. Polymer matrix granite particle composites have been widely used since the mid 1970s [14] in machine tool structures, and in general measuring and analysis devices [15,16], particularly due to its high vibration absorption capacity compared to common structural materials. Synthetic granite composites are still advantageous because it allows the inserts application in the functional parts of the equipment, fluid and spinning ducts, voids of mass relief, lifting inserts and still allows the use of industrial waste, conferring an advantageous environmental and economic character to the material $[15,17,18]$.

In this work an improvement of the common synthetic granite is presented, where refined gravel with size of $\emptyset \max =2 \mathrm{~mm}$ was used, epoxy resin with high mechanical resistance and, for some specimens, 
reinforcement of segmented carbon fibers were applied. Such composition is directed to manufacturing of precision equipment that requires thin walls conjugated with mechanical strength and high vibration absorption.

\section{MATERIALS AND METHODS}

For the specimens preparation was used gravel of Cinza Mauá Granite, abundant in the southeast region of Brazil $[19,20]$, and Araldite ${ }^{\circledR}$ high strength epoxy resin LY 5052 with a tensile strength of $82 \mathrm{MPa}$ according to the manufacturer. Torayca ${ }^{\circledR}$ brand T300 segmented carbon fibers with diameter of $8 \pm 0.5 \mu \mathrm{m}$ with $2.5 \mathrm{~mm}$ lengths washed with isopropyl alcohol were used in flexural tests. Also was used the equipment Ohaus ${ }^{\circledR}$ model Precision Standard for mass measures and were followed the resin specifications for material cure.

Three bands of gravel granulation were used, the "coarse" strip being composed of gravel stones of size $1.2 \mathrm{~mm}$ to $2.0 \mathrm{~mm}$, "medium" from $0.3 \mathrm{~mm}$ to $0.6 \mathrm{~mm}$ and "fine" from $0.1 \mathrm{~mm}$ to $0.2 \mathrm{~mm}$. This granulometry followed the stone size ratios used by RAMOS et al. [15]. In order to determine the proportion of the three ranges of stones used in the bulk packing, 66 measurements of the compaction level were carried out by reading the volume occupied by a fixed mass of gravel stones in a test tube, according to standards ABNT NBR 12173 and ABNT NBR 248 [21,22]. With the measured values a ternary diagram of the resulting densities of each proportion tested was plotted, shown in Figure 1.

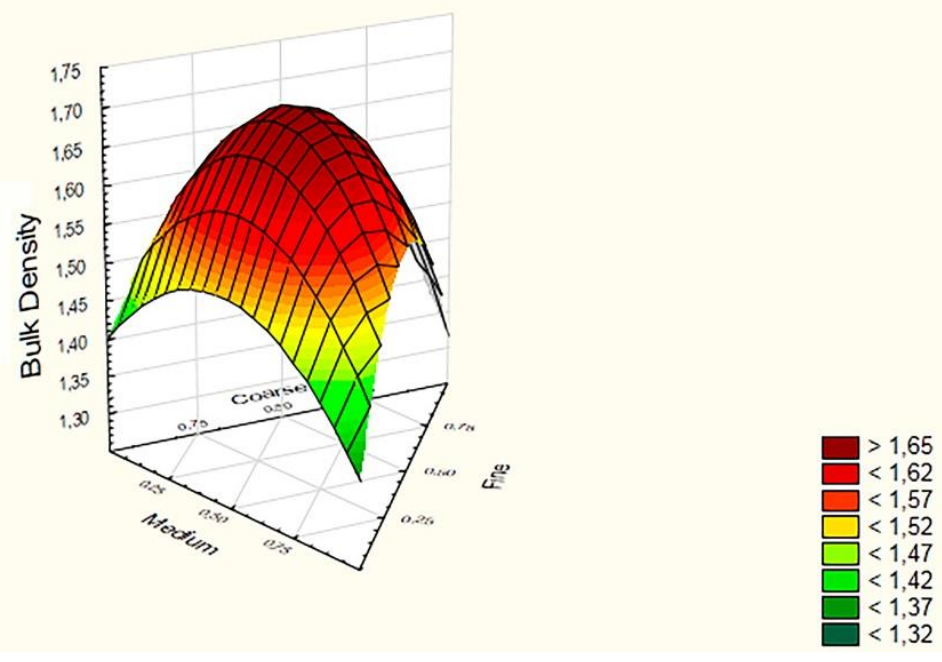

Figure 1: Bulk composition ternary diagram.

It was observed, through the ternary diagram made (Figure 1), that the proportion of stone sizes tested that resulted in the best packing was: 55\% coarse, 15\% medium and 35\% fine. This proportion resulted in greater densification reaching an apparent density of $1.75 \mathrm{~g} / \mathrm{cm}^{3}$. Hence such proportion of stone size was chosen to make the synthetic granite composite focus of this work by ensuring the lowest resin consumption, in this way only $19 \%$ was added to the total mass of the stones resulting in a final material density of 2.1 $\mathrm{g} / \mathrm{cm}^{3}$, denominated composition A.

For the synthetic granite composite reinforced with carbon fibers manufacturing, the proportion between the granulations of stones was maintained. Only $0.5 \%$ by volume of carbon fibers of $2.5 \mathrm{~mm}$ in length was added to composition A, fiber-reinforced composition being referred to as composition B. Figure 2 shows the optical microscope image of a synthetic granite composite polished section in (a) of composition $\mathrm{A}$ and in (b) of composition B. 
(a)

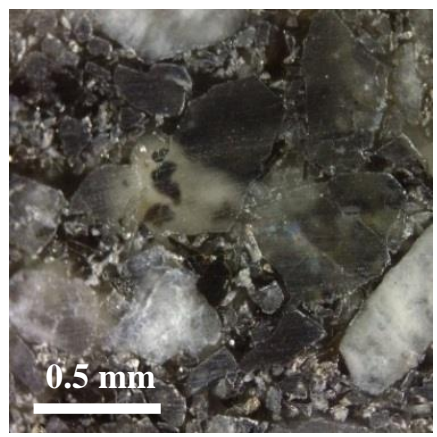

(b)

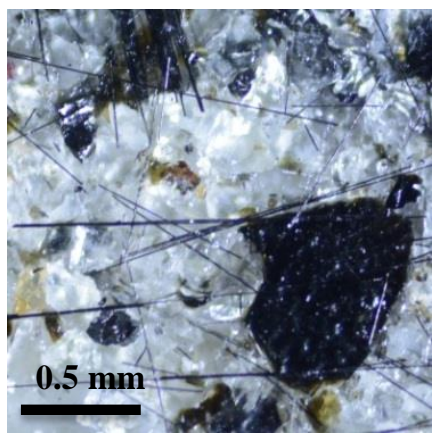

Figure 2: Polished section images. Unreinforced composition (a). Reinforced composition (b).

The granite stones processing generates jagged gravel and it favors the morphological fixation between gravel and the other components used in the composite formulations. The Figure 2 shows hall the medium and fine gravel fills the spaces between the coarse ones, also it is possible to observe the irregular gravel surface that favors composite phases anchorage. There was no sign of chemical fixing, as envisaged by literature $[9,18]$, between the material phases.

With the defined composition A of the synthetic granite, the specimens geometries were chosen for each test according to adequate standards and were performed specimens for tensile, flexural, compression, dilatometry, hardness, thermal conductivity and damping tests. For comparison with focused material of this study, aluminum and cast iron test specimens were also made for the damping test. Figure 3 shows the test specimens used.

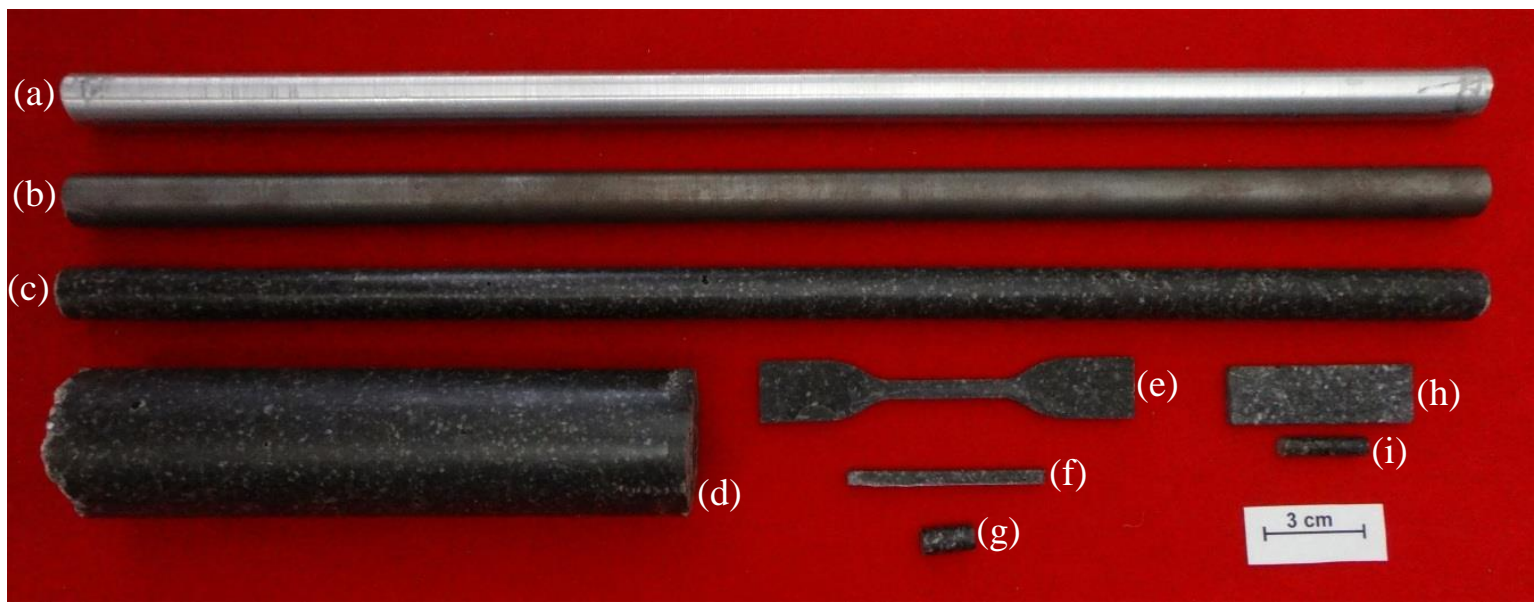

Figure 3: Test specimens. 6161 aluminum damping (a). Gray iron damping (b). Synthetic granite damping (c). Thermal conductivity (d). Tensile (e). Flexural (f). Compression (g). Microhardness (h). Thermal expansion (i).

For the mechanical strength tests a universal machine was used, model Bionix brand MTS®, with load cell of $15 \mathrm{kN}$. The tensile test followed ASTM D4762 [23], with a test speed of $0.07 \mathrm{~mm} / \mathrm{min}$. The flexural test followed ASTM D7264 [24], with a test speed of $0.1 \mathrm{~mm} / \mathrm{min}$. The compression test followed ASTM E2954 [25], with a test speed of $0.2 \mathrm{~mm} / \mathrm{min}$. Were produced 10 specimens for each mechanical strength test based on standards used.

To measure the material thermal expansion coefficient, was used equipment DIL $402 \mathrm{C}$ from the manufacturer Netzsch, were tested 10 specimens, according to ASTM E228 [26] with a heating rate of $2{ }^{\circ} \mathrm{C} / \mathrm{min}$. In the hardness test, a Leica microhardness equipment, model VMHT MOT was used for Knoop hardness measurement from the application of a load of 200 grams, to measure the hardness 5 specimens were produced and 10 measurements were taken on each specimen following ASTM E384 [27] recommendations. The equipment used allows the precise visualization of the chosen point for indentation, 
hence it was possible choose points in the resin phase and in the gravel phase. For the hardness measurement, due to the material nature, it was decided to perform measurements for the different phases, since such information may be required, but for the other properties the measurements were made considering the composite as a whole, in order to obtain better data to be used in projects with the material being studied.

The apparatus for measuring the material thermal conductivity was made with a thermal conductivity measurer of Hukseflux model TP-08 and a MINIPA ${ }^{\circledR}$ power supply model MPL-1303, were used 5 specimens. The data acquisition system and test procedure was based on the Standard ASTM D5930 [28].

The vibration damping test was performed with cylindrical specimens of 6061 aluminum, gray cast iron and synthetic granite composite. The specimens were suspended by elastic attached to the ends. A PCB Piezotronics model 353B16 accelerometer was attached to one end of the test body. The impulse was applied through the PCB Piezotronics model 086C03 impact hammer. The acquisition system used was Data Physics Quattro®. The damping coefficient $(\xi)$ was calculated by the logarithmic decrement method according to equation (1).

$$
\xi=\frac{\frac{1}{n-1}\left(\ln \frac{x_{1}}{x_{n}}\right)}{\sqrt{4 \pi^{2}+\left[\frac{1}{n-1}\left(\ln \frac{x_{1}}{x_{n}}\right)\right]^{2}}}
$$

To use equation (1) we choose two peaks $x_{1}$ and $x_{n}$ separated by (n-1) periods in the acceleration amplitude plot, plotted based on the accelerometer data.

\section{RESULTS AND DISCUSSION}

In the mechanical strength tests the composition A reached resistance of $27 \pm 3 \mathrm{MPa}$ in tensile, $103 \pm 5 \mathrm{MPa}$ in compression and $42 \pm 2 \mathrm{MPa}$ in flexural. Figure 4 shows the graphs of average tensions in the tensile, compressive and flexural tests.

(a)

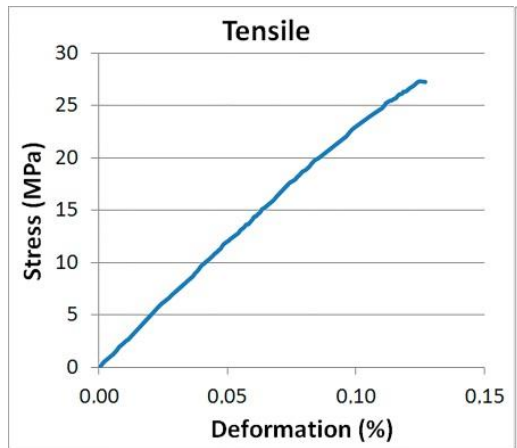

(b)

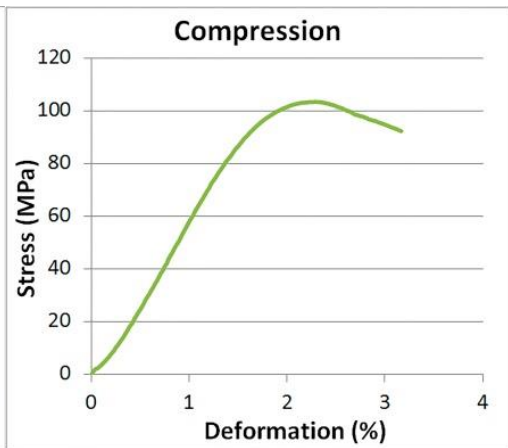

(c)

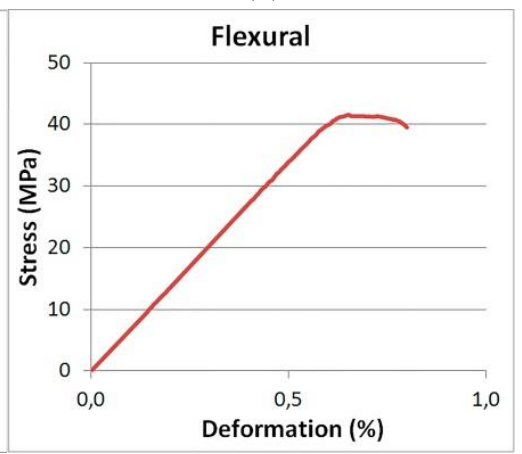

Figure 4: Average tensile (a), compressive (b) unreinforced flexural (c) results.

Composition A showed tensile and compression strengths gain of about $80 \%$ and $30 \%$ respectively compared to traditional synthetic granites formulations of literature [9]. This improvement was due to the use of a high strength resin which had a strong impact on the improvement of tensile strength however lesser capacity to increase the compressive strength compared to the traditional resins used in this class of composites $[9,15]$. The material reached tensile strength lower than pure epoxy resin and also was observed transgranular fracture on specimens of tensile tests, suggesting that for traction the polymer phase is the main responsible for the mechanical resistance. The results of tensile, compression and bending strength obtained are important in the evaluation of this material for use in mechanical structures.

The damping coefficient is the major highlight of the synthetic granite, it was measured in vibration tests through the response of an accelerometer adhered at the end of the bars that were subjected to an impulse. Figure 5 shows the decay graphs of the amplitude by time: 
(a)

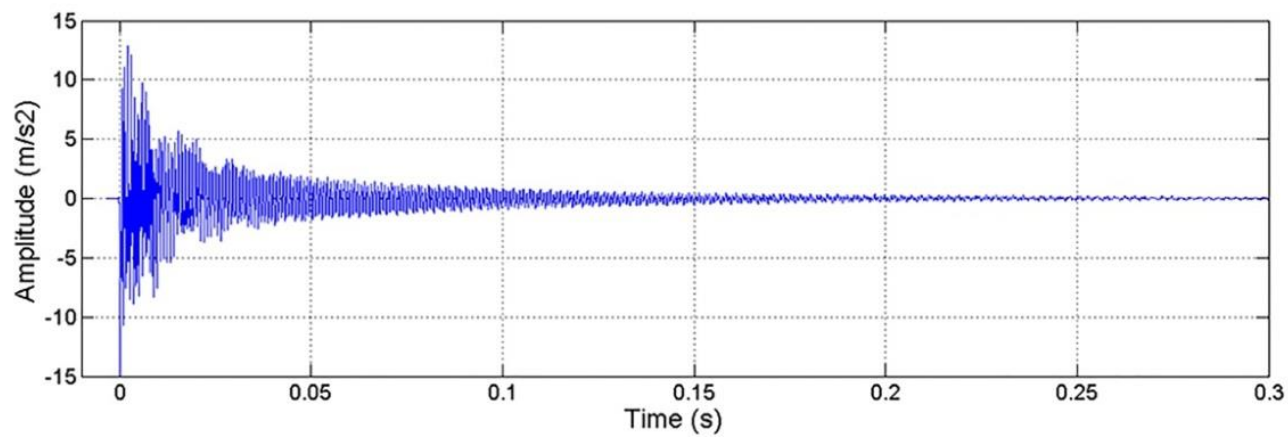

(b)

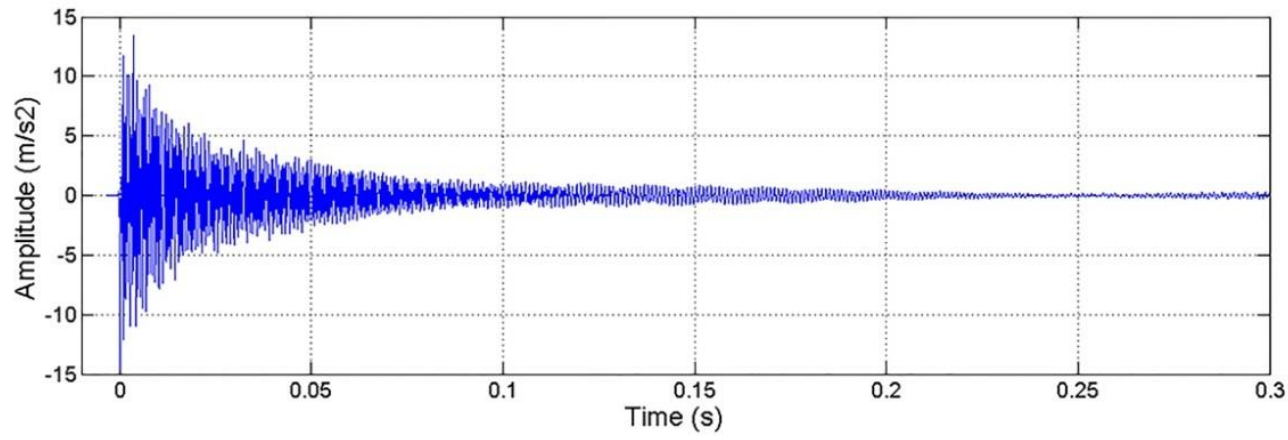

(c)

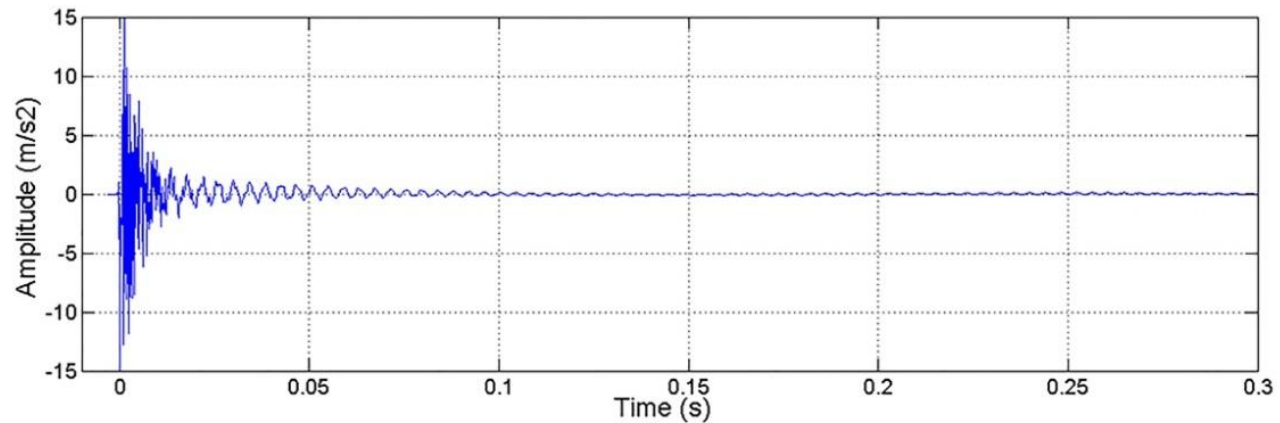

Figure 5: Amplitude variation of acceleration in time. Aluminum alloy 6061 (a). Grey cast iron (b). Synthetic granite (c).

The damping coefficient values by the Logarithmic Decrement Method [29] calculated for the three materials are shown in Table 1:

Table 1: Damping coefficient.

\begin{tabular}{l|l|l}
\hline MATERIAL & \multicolumn{1}{|c|}{$\bar{\xi}$} & Standard deviation \\
\hline Synthetic granite & 0.0181 & 0.0019 \\
\hline Aluminum 6061 & 0.0033 & 0.0005 \\
\hline Grey cast iron & 0.0029 & 0.0004 \\
\hline
\end{tabular}

The produced synthetic granite composite presented excellent average damping coefficient, 5.5 times greater than aluminum 6061 and 6.2 times greater than gray cast iron, two materials usually used in machine structures and precision equipment. These measured values of aluminum damping coefficient and cast iron 
damping coefficient are in agreement of literature [30-32], as well the damping coefficient measured by the granite composition [8,33]. These results show the advantage of synthetic granite for the vibrations absorption in mechanical structures, compared to metals traditionally used for this purpose, inciting its application in structures of machine tools and measurement machines.

In the dilatometry test, an average expansion of $1.4 \mathrm{E}-5(\mathrm{~m} / \mathrm{m} . \mathrm{K})$ was observed at working range temperature between $25^{\circ} \mathrm{C}$ and $80^{\circ} \mathrm{C}$, lower than that found in commercial aluminum alloys that are around $2.3 \mathrm{E}-5(\mathrm{~m} / \mathrm{m} . \mathrm{K})$ [1,34], and higher than gray cast irons ranging from $0.8 \mathrm{E}-5$ to $1.2 \mathrm{E}-5(\mathrm{~m} / \mathrm{m} . \mathrm{K})[1,34]$. Smaller values mean greater dimensional stability due to thermal variation so synthetic granite presents intermediate behavior between the considered materials. Therefore the measured value of the thermal expansion coefficient of the composite studied in the present work is satisfactory because it is within the thermal expansion coefficients range of metals commonly used for machine structures. The Figure 6 graph shows the behavior of thermal expansion coefficient in the temperature range tested.

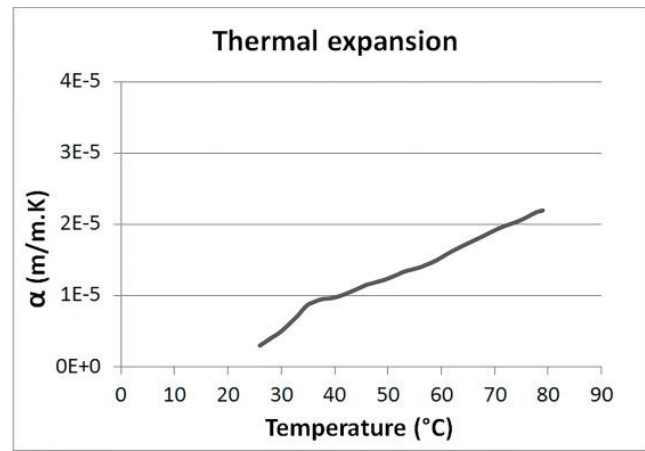

Figure 6: Thermal expansion composition A.

Hardness is an important property for specific applications because a body supported on the structure receives loads which can result in high stresses. In this sense Knoop micro hardness tests were performed and the results showed a great variation in the measurements due to the hardness of the material phases present in the cutting surface: resin and granite (quartz and feldspar). The hardness in the areas of resin presented values in the range between $25 \mathrm{HK}$ and $45 \mathrm{HK}$, in the stone areas in the range between $120 \mathrm{HK}$ and $360 \mathrm{HK}$ in agreement of literature [1,9,35]. For aluminum alloys and gray cast iron (class 20-40) the hardness is in the range of $88 \mathrm{HK}$ and $170-260 \mathrm{HK}$, respectively [1,35], therefore, in relation to hardness the behavior of synthetic granite developed can be considered as an intermediate and consequently suitable for machine structures manufacture.

Excessive heat concentration can generate local deformations in machine structure and must be considered by design. The structural material must have suitable heat conduction coefficient to avoid thermal distortions. The results of conductivity were $1.2 \pm 0.1 \mathrm{~W} / \mathrm{m} . \mathrm{K}$ for the synthetic granite composition tested, lower than general metals alloys, (generally over then $10 \mathrm{~W} / \mathrm{m} . \mathrm{K}$ ) [1,3], although still higher than general polymers (commonly less than $0,7 \mathrm{~W} / \mathrm{m} . \mathrm{K}$ ) and some types of composites [1,3]. Then for regions of machine structures made of synthetic granite where it is necessary to receive and dissipate heat quickly by conduction, a possible solution would be the use of metallic inserts.

Composition B was tested in a flexural test to evaluate the gain in mechanical strength with carbon fibers addition. The resulting graph of the bending tests of composition B is shown in Figure 7. 


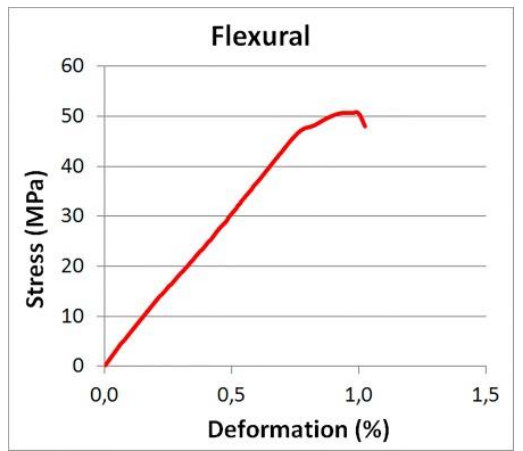

Figure 7: Average flexural reinforced result composition B.

It was observed $51 \pm 2 \mathrm{MPa}$ average flexural strength of composition B with gain of $20 \%$ relative to composition $\mathrm{A}$, due to the reinforcement of the carbon fibers tests with larger fibers and with a higher concentration of fibers were made and presented increase in the mechanical strength, however the increase in the proportion or length of the fibers impaired the packing, requiring the increase of the resin proportion and for this work it was chosen to maintain the proportion of resin in the material for both composition A and composition B. in Table 2.

The synthetic granite developed, made and tested in the present work presented the properties shown

Table 2: Properties summary.

\begin{tabular}{c|c|c|c|c|c|c|c|c}
\cline { 2 - 8 } & $\boldsymbol{\mu}\left(\mathbf{g} / \mathbf{c m}^{3}\right)$ & $\boldsymbol{\sigma}_{\mathbf{t}}(\mathbf{M P a})$ & $\boldsymbol{\sigma}_{\mathbf{c}} \mathbf{( M P a )}$ & $\boldsymbol{\sigma}_{\mathbf{f}} \mathbf{( M P a )}$ & $\boldsymbol{\alpha}(\mathbf{m} / \mathbf{m} \cdot \mathbf{K})$ & $\mathbf{H K}$ & $\boldsymbol{k}(\mathbf{W} / \mathbf{m} \cdot \mathbf{K})$ & $\xi$ \\
\hline \multirow{2}{*}{ Synthetic granite } & 2.1 & $27 \pm 3$ & $103 \pm 5$ & $\begin{array}{c}42 \pm 2 \\
* 51 \pm 2\end{array}$ & $1.4 \mathrm{E}-05$ & $25 \sim 360$ & $1.2 \pm 0.1$ & $0.018 \pm 0.002$ \\
\hline
\end{tabular}

*Composition B.

\section{CONCLUSIONS}

Synthetic granite composite presents itself as a valuable alternative for precision machine structures manufacturing and has been explored since the 1970s. However, with the evolution of commercial epoxy resins and the introduction of carbon fiber, it was demonstrated in this work the possibility of a gain of up to $70 \%$ in flexural strength compared to traditional literature compositions. The developed composition showed remarkable ease of manufacture and enormous vibration damping capacity, among other good properties as a structural material.

With the composition of synthetic granite composite developed and tested its capacity is renewed for use in precision equipment structures with highlight to design concepts and prototypes. With respect to sustainability and depending on the granulometry of the grave used, these can be taken advantage of the immense ornamental stone industry waste and additionally the carbon fibers, in the length used, can also be obtained from composite industry leftovers, so that more than $80 \%$ of the material mass of the present work can be obtained as disposal material of other industrial processes and still with low energy consumption.

\section{ACKNOWLEDGMENTS}

The authors are thankful for their research grants (CAPES and CNPq).

\section{BIBLIOGRAPHY}

[1] ASHBY, M. F., Materials Selection in Mechanical Design, 3 ed., London, Butterworth Heinemann, 2005.

[2] LIANG, Y., CHEN, W., SUN, Y., et al., "A mechanical structure-based design method and its implementation on a fly-cutting machine tool design", International Journal of Advanced Manufacturing Technology, v. 70, n. 9, pp. 1915-1921, Nov. 2013. 
[3] LUCISANO, S., MILADIN, S., FRAGASSA, C., "Advanced design solutions for high-precision woodworking machines", International Journal for Quality Research, v. 10, n. 1, pp. 143-158, 2016.

[4] THE ROYAL ACADEMY OF ENGINEERING, Philosophy of Engineering, 1 ed., London, 2010.

[5] DEHGHAN-MANSHADI, B., MAHMUDI, H., ABEDIAN, A., et al., "A novel method for materials selection in mechanical design: Combination of non-linear normalization and a modified digital logic method “, Materials and design, v. 28, n. 1, pp. 8-15, Aug. 2005.

[6] EDDY, D., KRISHNAMURTY, S., GROSSE, I., et al., “A Robust Surrogate Modeling Approach for Material Selection in Sustainable Design of Products", In: Proceedings of the ASME 2014 International Design Engineering Technical Conferences \& Computers and Information in Engineering Conference, pp. 118, Buffalo, Aug. 2014.

[7] MEHRABI, M. G., ULSOY, A. G., KOREN, Y., "Reconfigurable manufacturing systems: key to future manufacturing”, Journal of Intelligent Manufacturing, v. 11, n. 4, pp. 403-419, 2000.

[8] PIRATELLI-FILHO, A., LEVI-NETO, F., "Behavior of composite granite-epoxy bars subjected to mechanical vibrations”, In: VI National Congress of Mechanical Engineering, Campina Grande, Aug. 2010.

[9] KAMATH, S., D'MELLO, J., BALAKRISHNA, S. S., "Experimental study on mechanical properties os red granite-epoxy particulate composites", International Journal of Mechanical Engineering and Robotics Research, v. 3, n. 4, pp. 178-187, Oct. 2014.

[10] AGGOGERI, F., BORBONI, A., MERLO, A., et al., "Vibration Damping Analysis of Lightweight Structures in Machine Tools", Preprints, v. 1, pp. 1-14, Dec. 2016.

[11] ERGUIA, J., URIARTE, L., LAMIKIZ, A., “Analysis, optimization and accuracy assessment of specialpurpose portable machines by virtual techniques", International Journal of Machine Tools \& Manufacture, v. 111, n. 1, pp. 31-42, Sep. 2016.

[12] PARUCKER, M. L., KLEIN, A. N., BINDER, R., "Development of sintered nickel alloy by powder injection molding”, Matéria, v. 19, n. 3, pp. 218-227, Sep. 2014.

[13] BIKAS, H., STAVROPOULOS. P., CHRYSSOLOURIS, G., “Additive manufacturing methods and modeling approaches: A critical review", International Journal of Advanced Manufacturing Technology, v. 83, n. 4, pp. 389-406, Jul. 2015.

[14] SERVO, J. C. P., Seleção de um material alternativo para a estrutura de máquinas-ferramentas de arranque de apara, Dissertation M.Sc., Minho University, Braga, Portugal, 2013.

[15] RAMOS, D. T. L., PALLONE, E. M. J. A., PURQUERIO, B. M., et al., "Design and construction of a pin-on-disc bench for wear testing”, Cerâmica, v. 60, n. 355, pp. 443-448, Jul. 2014.

[16] MURUGAN, S., THYLA, P. R., "Investigation on Dynamic Analysis of VMC Bed using epoxy Composite", Carbon - Science and Technology, v. 7, n. 4, pp. 66-75, Dec. 2015.

[17] SOUZA, L. G. M., SANTOS, N. R., CAVALCANTE, A. A., et al., "Composite utilizing residues of marble and granite for building popular homes", Jornal of Building Engineering, v. 9, n. 1, pp. 192-197, Jan. 2017.

[18] GONÇALVES, J. A. V., CAMPOS, D. A. T., OLIVEIRA, G. J., et al., "Mechanical Properties of Epoxy Resin Based on Granite Stone Powder from the Sergipe Fold-and-Thrust Belt Composites", Materials Research, v. 17, n. 4, pp. 878-887, Aug. 2014.

[19] DEL LAMA, E. A., DEHIRA, L. K., GROSSI, D., KUZMICKAS, L., "The colour of the granite that built the city of São Paulo, Brazil”, Color Research \& Application, v. 41, n. 3, pp. 241-245, Dec. 2015.

[20] ALVER, A., JANASI, V. A., SIMONETTI, A., et al., "Microgranitic enclaves as products of selfmixing events: a study of open-system processes in the Mauá Granite, São Paulo, Brazil, based on in situ isotopic andtrace elements in plagioclase”, Journal of Petrology, v. 50, n. 12, pp. 2221-2247, Dec. 2009.

[21] ASSOCIAÇÃO BRASILEIRA DE NORMAS TÉCNICAS. NBR 12173: "Fine-grained refractory materials - determination bulk specific gravity". Rio de Janeiro, 2012.

[22] ASSOCIAÇÃO BRASILEIRA DE NORMAS TÉCNICAS. NBR 248: "aggregate materials determination bulk composition". Rio de Janeiro, 2003.

[23] AMERICAN SOCIETY FOR TESTING AND MATERIALS. ASTM D4762: "Standard guide for testing polymer matrix composite". West Conshohocken, 2016. 
[24] AMERICAN SOCIETY FOR TESTING AND MATERIALS. ASTM D7264: "Standard test method for flexural properties of polymer matrix composite materials". West Conshohocken, 2015.

[25] AMERICAN SOCIETY FOR TESTING AND MATERIALS. ASTM E2954: "Standard test method for axial compression test of reinforced plastic and polymer matrix composite vertical members". West Conshohocken, 2015.

[26] AMERICAN SOCIETY FOR TESTING AND MATERIALS. ASTM E228: "Standard test method for linear thermal expansion of solid materials with a push". West Conshohocken, 2016.

[27] AMERICAN SOCIETY FOR TESTING AND MATERIALS. ASTM E384: "Standard test method for microindentation hardness of materials". West Conshohocken, 2016.

[28] AMERICAN SOCIETY FOR TESTING AND MATERIALS. ASTM D5930: "Standard test method for thermal conductivity of plastics by means of a transient". West Conshohocken, 2016.

[29] OGATA, K., Modern Control Engineering, 5 ed., Upper Saddle River, Pearson, 2009.

[30] FRANCESCHINI, J. GOMES, H. M., “Avaliação de amortecimento estrutural usando-se o método do Random Decrement”, Engenharia Estudo e Pesquisa, v. 10, n. 1, pp. 39-48, Jan. 2010.

[31] MAHENDRAKUMAR, N., SYATHABUTHAKEER, S., MOHANRAM P., "Study of alternative structural materials for machine tools", In: XXVI All India Manufacturing Technology, Design and Research Conference, Guwahati, Dec. 2014.

[32] SUBRAHMANYASWAMY, S., SREEDHAR, B. R., CHANDAN, K. M., et al., "Influence of resin content and cast iron powder addition on vibration characteristics of granite epoxy composites", International Journal of Innovative Research in Science, v. 3, n. 7, pp. 14578-14588, Jul. 2014.

[33] SELVAKUMAR, K., GANESAN, K., MOHANRAM, P. V., "Dynamic analysis on fabricated mineral cast lathe bed”, Journal of Engineering Manufacture, v. 227, n. 2, pp. 261-266, Nov. 2012.

[34] HIBBELER, R. C., Resistencia dos Materiais, 5 ed., São Paulo, Pearson, 2004.

[35] VLACK, L. H. V. Materials for Engineering: Concepts and Applications, 1 ed., Reading, AddisonWesley, 1982. 